\title{
(Un)civil society in Bosnia and Herzegovina: Readiness to commit violence and the ethnicization of society
}

https://doi.org/10.1515/openps-2018-0007

received March 10, 2018; accepted October 15, 2018.

\begin{abstract}
The collapse of institutional and state structures in Bosnia and Herzegovina has rendered the populace unprotected in financial, social, and legal terms and pushed it, under the aegis of local ethnocracies, into personal or local ethnic networks. The text examines identity issues in Bosnia and Herzegovina with the particular emphasis on ethnic divisions and the lack of civic values.
\end{abstract}

Keywords: Bosnia and Herzegovina; civil society; the Balkans; identity.

The collapse of institutional and state structures in Bosnia and Herzegovina has rendered the populace unprotected in financial, social, and legal terms and pushed it, under the aegis of local ethnocracies, into personal or local ethnic networks. In addition, the previous autocratic system has left not only its typical legacy of a poorly organized civil society but has, in the case of Bosnia and Herzegovina, also left a permanent mark on people's attitudes and values. ${ }^{1}$ Existential and ethnic strife was not the cause of the escalating violence. To the contrary, the causation runs the other way: the collapse of the institutional framework paved the way for further ethnicization and the decline of civilized society at the national level, as well as the privatization of violence. ${ }^{2}$ This "top-down" moulding of identity by means of indefinite symbolic messages subsumed the (civil) society under the concept

*Corresponding author: Mensur Kustura, Faculty of Law, University in Travnik, Kiseljak, Bosnia and Herzegovina, E-mail: Mensur92@ yahoo.de

Kristina Knezevic: Faculty of Law, University of Travnik, Bosnia and Herzegovina

Lana Šabani: Faculty of Law, University of Zenica, Bosnia and Herzegovina

1 Merkel; Puhle, 2003: 222

2 Rüb, 2000: 188 of a nation, exchanging the diversity of social actors for the notion of a compact nation. In the context of radicalized multi-ethnic societies, the deciding factor is the control of arms. Uncivil society leads to armed conflict, during which the state's monopoly over exercising violence is abolished and coercion is either privatized or delegated to society. When state mechanisms are absent and there is no one to hold the reigns of political power, all differences, following a friend-or-foe pattern, are viewed through the eyes of private interests. If this differentiation is not visible in state institutions, but rather in small groups - as is typically the case when state structures have fallen apart - the friend-or-foe paradigm is extended ad infinitum. The anti-liberal and patrimonial strategy of incorporating populist movements has found fertile ground here. Incorporated into ethno-social movements, the "national question" has taken on the role of a mobilizing factor, growing into a relatively stable fusion of nationalism, religious fanaticism, social solidarity, and anti-communism. According to this scheme, a significant factor within the political culture for the mobilization of ethno-nationalistic movements is the varied perception of the nature of the national character. This has contributed heavily to making the tabooed national question a mobilizing factor for anti-civil social actors, and relegated other issues of importance to the shadow of social events. In the scheme of populism, the established relationship matrix between the "civil and social" actors on the one hand and the state on the other no longer provided the support needed by a young liberal democracy. Major sections of the population were not integrated into the political community by being guaranteed their social rights, but were incorporated in by a "caretaker" state that guaranteed their political and economic rights. The decisions with respect to the demands of individual actors were not reached in a publicly supported process comprised of discussion and negotiation, but rather in isolated arenas of communication that excluded the civil society at large and the accompanying debate process.

ə Open Access. (c) 2018 Mensur Kustura et al., published by De Gruyter. $\Subset$ Br-Nc-ND This work is licensed under the Creative Commons Attribution-NonCommercial-NoDerivatives 4.0 License. 
The diffuse support offered by civil and social actors for what were deemed legitimate institutional structures for resolving cultural, ethnic, armed and political conflicts stymied the process whereby they could take their proper shape.

In turn, the lack of procedural legitimacy called into question the political regime's stability, especially at the time when the initial integrating force of the inceptive myths was waning, and the demanded objectives could not be achieved in a constructive manner. In such a setting, the notions of individual civil rights and liberties and of a negative freedom from state interference could hardly be realized. Only a handful of civil and social actors became engaged in the protection of individual or minority rights (ethnic, racial, linguistic or gender). While the relationship between the political ethnic elites and power cartels was already marked by profound discord, the main problem was that the increase in ethnic strife and violence had originated "top-down" and had by then careened out of control of the political elites themselves. Individual liberties include the freedom to change or confirm cultural, religious, ethnic or national identities, and the concomitant possibility to resolve conflicts through debate. If the civil society in general is weak, and if there are minorities of various kinds, they require a special form of protection from the majority, and this protection gains credibility and reliability in unison with a system of guaranteeing legal liberties. An active civil society is complemented by a passive civil society, and a prerequisite to its existence is an effective state vouching for its liberties via the law and institutions.

In comparison to other civil and social movements in Central and Eastern Europe, the actors in Bosnia and Herzegovina were not constitutionally oriented. ${ }^{3}$ Social trust stands out as the most important factor among the elements comprising social capital, along with the willingness to actively participate in civil and social organizations. Only when there is sufficient social trust is a lasting peaceful and non-governmental social cooperation possible. A lack of interpersonal trust engenders distrust in democratic institutions: "The levels of social trust in Bosnia and Herzegovina are low, but within the norm found in other post-communist European states. What presents a cause of concern are the low levels of trust between the three national groups. A high level of loyalty within groups, matched by distrust towards other national groups, does not make for a sound foundation for political development." ${ }^{4}$ It is apparent that

3 Ibid, 2000: 185

4 Ibid, 2000: 185 there is a strong intragroup loyalty between the members of the same ethnic group, which may be regarded as a cohesive social capital, but it is accompanied by high levels of distrust directed at the members of other ethnic groups. This disrupts the institutional establishment of a stable, socially legitimate and socially responsive party subsystem and the build-up of social trust in institutions safeguarding the political and legal order. A representational vacuum thus looms at the level of political society. Another hindrance is the lack of trust in the construction of any civil space which counteracts the state, the sort of which is, according to Tocqueville, the best safety mechanism against state despotism and the democratic tyranny of the majority. ${ }^{5}$ In addition to there being no points of agreement on what form the political community should take, it is worth taking note of the fact that the citizens of Bosnia and Herzegovina demonstrate extremely low levels of trust in the premise of a deliberative democracy. This indicates the absence of the civil and social legitimacy which is essential in times of political crisis and which enables a democratic order to overcome such deficits. These results point to a latent danger that in exigent situations the citizens of Bosnia and Herzegovina might resort to some undemocratic solutions. ${ }^{6}$ Their long experience of a communist oneparty government, lack of general social consensus, as well as rapid disillusionment about the outcome of the changes in the political and economic system in Bosnia and Herzegovina have been the midwives to a type of political culture which is antagonistic to civil society.

During the communist system in Bosnia and Herzegovina certain basic concepts of a pluralistic civil society were absent, including the notion of grassroots organizations and bottom-up social movements, which could spring up to counteract state-controlled institutions, or at least act independently of them. A majority of the population took a relatively passive stance towards the communist regime, in line with the unspoken social contract between the citizens and the authoritarian government, whereby the regime guaranteed its citizens a certain standard of living and social security, and in return the citizens gave up their social and political participation and retreated into the private sphere of life. While the trust in institutions in Bosnia and Herzegovina is extremely low compared to other former communist countries, there is still an expectation that the state bears the responsibility to maintain law and civil order, as well as guarantee social security. This attitude gave rise to an alienated

5 Merkel; Puhle, 2003: 217

6 Salaj, 2009: 87 
paternalistic political culture with a tendency towards authoritarianism, nationalism, and particularism. Consequently, the mobilizing potential of civil and social groups is very low. Citizens who trust each other are those most likely to join civil and social organizations and thus contribute to the development of an active society. If other spheres, including independent media, a critical populace and subcultures, fail to develop, civil society cannot fulfil its tasks in the process of democratization. The increase in responsibility accompanying the development of civil society implies that such a society should espouse a high level of self-reflection regarding its engagement and should respect the decisions reached through a democratic, legitimate procedure. This by no means implies that all such decisions should be accepted with approbation. But the self-critical readiness of social actors to (self)reflect is imperilled when a conflict arises between the democratically-made decisions and one's own program goals. It should be noted that there is no systemically cogent argument or theory that conveys a preponderant normative legitimacy to the forms and substance of civil society's interactions over those of the representative procedural mechanisms and over democratic outcomes.

Still, the processes described above cannot take place without social and political participation. Reformist social movements inspired by civil society and the strivings of social groups for political and social reforms within the established order confirm that the democratic defects of state and law are by no means unequivocally accepted by the citizenry. The most salient demand is that the political elites be open for learning. Civil society is the sole open space for the development of civil initiatives and the framing of demands upon the political and administrative subsystem. However, in Bosnia and Herzegovina we have an inefficient state and a listless society, as well as numerous groups and networks that arose following the armed conflict. While these can be subsumed under the category of voluntary associations, they are difficult to classify within a democratic society since they can evolve into undemocratic and consequently uncivil groups in a negligible time span. There is also a latent danger that certain groups and individuals, which might initially be classified as constituents of a democratic civil society, may evolve into uncivil groups under unfavourable political and social conditions, especially in the context of political elites which deliberately politicize ethnicity. When political parties mobilize their supporters along ethnic lines and political conflicts are based on the clash of identities, there is a danger of ethnic conflicts becoming political conflicts. Such conflicts can inflict lasting damage to equal opportunities for political participation. The democratic question is posed differently at the phenomenological plane, reflecting the interaction between the plurality and the intensity of conflict in civil society, i.e.: In what way and by what means can the obstacles to the coexistence of various groups and organizations in a democratic civil society be removed, so as to bar an escalation to a "civil war" and refrain from violently affirming any theory which places the political ontology in friend-or-foe relations? The destruction of all symbols of inimical coexistence by means of the total instrumentalization of conflict in internal political power struggles reveals that social conflicts can exceed the level of civilized dissent and evolve into long-lasting confrontations between hostile political philosophies. This is evident in the example of Bosnia and Herzegovina, where a short-lived thaw in the 1980s, bringing about civil and social concepts and the accumulation of social capital, promptly transformed into the ethnicization of Bosnian and Herzegovinian society. What this effectively amounted to were ethnically "homogenous" communities, whose internal social capital was generated at the cost of erecting borders and instigating fighting with other ethnic communities. Like the Ku-Klux-Klan and SA units, ethnic militias in Bosnia and Herzegovina and Lebanon, or fundamentalist religious communities form social networks and formal associations which generate social capital exclusively for their members. They seal themselves off to other ethnic and religious communities. This barrier is often fortified through distrust and intolerance, and sometimes even by blatant violence. The existing ethnic "rifts" may be widened through civil and social activities. The hierarchical and nepotistic character of civil and social organizations, coupled with the frustration of civil actors over the snails' pace of consolidation processes, may abruptly transform into political apathy or even eagerness to take part in violent actions against the new democratic state, which thus falls into disfavour just like the previous state.

The formation of a pluralistic civil society is very complicated in the context of the existing ethnic issues. These issues are manifested in deep cultural and socioeconomic fault lines. A successful integration of different ethnic identities always involves bringing the differences together, and in such a case the growing possibility of social integration presents a great danger to the vested interests of political elites, who then portray it as a danger to the identity of their clients. Civil and social organizations are partly intertwined with these existing cleavages, leading to a cultural and ethnically-induced segmentation of the civil society. It is characteristic of 
ethnically segmented civil and social structures that they endorse associations and movements which espouse ethnic criteria. These organizations endeavour to sever the potential or real attachments of citizens to various outside interest groups, and seek to consolidate in their own entity the reason d'être of such groups by publicly championing different causes separately from the existing relevant voluntary associations, thus diverting their share of public relevance to themselves and garnering a high level of importance (legitimacy) and political clout by exacerbating the ethnic divisions. The civil society in Bosnia and Herzegovina is undoubtedly peppered with groups and movements which practice and advocate anti-civic values. They certainly don't promulgate core democratic virtues such as civility, in the sense of tolerance, recognition, respect and non-violence, and especially not with those persons who are not among their own active membership. To the contrary, the fundamental premises of their group cohesion are the negative classifications of and deprecatory attitudes directed at certain ethnic groups, i.e. exclusion and hostility towards these groups. Such actors are the carriers of anti-civic stereotypes, leading to social distance and prejudice, although one can still observe efforts on the part of some civil and social groups to rise above this segmentation in society.

The most harrowing indirect threat to a democratic transition is constituted by the numerous local conflicts in the multi-ethnic society, which could escalate into serious violence and thus disrupt the social order. So the issue at hand is how to remedy the deteriorating situation by rebuilding trust, and in consequence civility, in a society ravaged by war, persecution and genocide. Deeply divided societies are characterized by vast rifts which divide religious, ethnic and cultural communities, based on clashing values, interests and identities. Added to the problems is the fact that in ethno-nationalist wars violence becomes the dominant mode of social communication, and further develops into a self-referential and selfperpetuating subsystem. Instituting civility means civilizing politics and social coexistence by external powers and providing the constitutional, institutional and practical preconditions by which social actors can alter themselves, and through their cognitive, emotional and psychological efforts advance toward a violence-free environment. The causes of conflicts are often ethnic, religious, social, and political combined. Religious and ethnic affiliations in many cases coalesce with the assignment of economic status. ${ }^{7}$ An increasing number of active citizens fail to see their interests represented

7 Ibid. 2009: 115 in the institutions of the parliamentary system and by the powerful elites whom they elected and to whom the governance was entrusted, which results in a growing voter apathy. This social frustration is manifested in regressive protest behaviours, and in citizens devoting themselves to secluded and hedonistic styles of life. The implications of this evolution are that we face serious risks in terms of the loss of civil properties of the society and the failure of the political power to gain independence, which in turn calls into question the democratic resources and the legitimacy of the political subsystem. ${ }^{8}$ This is so because every truly democratic process of forming opinions and goals via political parties and parliaments refers back to the sources of informal public opinion, so that they can form outside the political framework (i.e. not by the force of political will). This presupposes the existence of fundamental human rights for all citizens, including minority rights (ethnic, gender, race, language rights etc.), the openness of power and government structures, transparency and rational decision-making, political equality, and equal access to resources. The neglect of equal political and civil rights in young democracies is made worse if it is accompanied by the incomplete formation of a political community and by a politicized religious and ethnic segmentation of the society.

Herein lies the quandary faced by the Bosnian civil society in this interactive arrangement: it was these very ethnic and religious groups who were most outspoken when the authoritarian regime was being dismantled. Self-organization and activities in the informal sector are not the sole avenues of reaction to a political crisis of state legitimacy. A psychological propensity for the massive use of violence correlates with social destitution, but also can be the result of the instrumentalization of ethnic identities. This is made easier for the political elites due to the many civil and social groups being formed along ethnic lines. To prevent this, the present quandary must be resolved. On one hand, the rise of civil society involves purposeful civic participation (which is lacking at the present moment), while on the other hand intermediary subsystems can contribute significantly to strengthening civic participation. The process of empowering civil society would be bolstered if the participation were to move beyond its current weak presence. In conditions of social disorder and organization according to ethnic allegiances, apathy constitutes a viable survival strategy, since ethnic identity is easy to mobilize and leads to homogenous, sustainable communities of solidarity, feeding off of its members' emotional relations. But these

8 Müller, 1997: 328 
make up democratically illegitimate elites and power groups, which evade government authority and, as a result of their wide latitude, derive special constitutional, uncurbed benefits.

A completely dysfunctional state; the collective sense of loss of values and identity related to social and existential insecurity; and, given the pervasive violence, the obvious moral decadence; all these add up to a weak core commitment to non-violence, and lead to a situation wherein a self-centred attitude and disregard of the public good become the norm in public life. Some authors consider these examples of socialization to be correlated to the exacerbation of clash lines in civil society, and offer them as an explanation for the unprecedented level of violence in Bosnia and Herzegovina, which has eluded no part of the populace. A salient example is the active participation of the entire nation, including some clearly defined religious organizations, in crimes committed against members of other ethnic groups, ${ }^{9}$ while civil society and social organizations should offer their support, as well as the development of their civic competencies, to those groups promulgating coexistence with other cultures, religions and ethnicities. Democracy in Bosnia and Herzegovina has proven to be quite lacking in this respect.

The overall development of a defective democracy in the country has been aided by certain political and cultural specificities which proved to be of incalculable benefit in the construction of a communist and authoritarian regime in the past. There is an absence of legal, governmental and democratic traditions, and an almost complete absence of a tradition of resistance to a despotic or totalitarian government. ${ }^{10}$ Furthermore, the Catholic and the Orthodox churches have proven to be less outspoken with respect to the regime in the new democratic context than, for example, the Catholic church in Poland in the 1980s. There is no discernible, distinct transition to democracy, since there was no social actor in the form of a religious, ethnic or political movement powerful enough to claim power and authority in the new order.

But how does one achieve this structure of civil society, if the criteria of nonviolence, consensus, civic culture, tolerance and fairness are lacking? The envisaged goals of ethnic social movements called into question the status of "other nationalities". This contradicts the norm and practice of recognizing "the other" (tolerance), and thus physical violence and ensuing acts of barbarism could no longer be precluded. Thus, the ethnically

9 Schmidt, 2000: 324

10 Merkel; Puhle, 2003: 184 charged civil and social associations of Croats, Serbs and Bosnians cannot be regarded as segments of a civil society if tolerance, fairness, and respect for human rights and freedom to communicate - which, granted, are developed in an international context - are not only not observed, but are perverted into intolerance, stereotypes and violence when dealing with other ethnic communities. So long as a social actor with a potentially exclusive political agenda wishes to install democracy, and then use the newly acquired power to fulfil the objectives of his agenda, this will invariably lead to the perversion of civic virtues - tolerance, faimess, nonviolence, ability to compromise, reliability, empathy - within this ethnic community, and result in the exploitation of uncivil (violent) potential towards other ethnic, cultural or gender communities. Granted, civil and social structures may give the possibility of civic engagement (political participation), but often they exhibit only limited democratic behaviour and culture due to their internal oligarchic structure. Thus, it is a distinct possibility that personal allegiances and communication networks within these structures can be channelled through tested pathways of conflict and fortify the lines of separation and distinction, which in turn can lead to increased ignorance about and alienation from other groups and minorities. Bosnia and Herzegovina is a case in point for this scenario, especially following the overtaking of civil society by nationalistic and extremist forces, which tightly constrict the autonomy of civil society and curb its democratic potential. ${ }^{11}$ And if the conflicts within the political and social elites are more polarized than in the society at large, and if the elites collaborate directly with the radicalized elements in the society, this can only heighten the ethnic and social tensions.

The extent to which a civil society is required for a democracy to succeed depends on its character. Insights gained from contextually dependent assessments of civil society in Bosnia and Herzegovina reveal a meticulous localization in the processes of stabilization and democratic consolidation in the country. An important reason for this, according to Lauth, frequently lies in the existential conditions pertaining to the local and regional settings, and sometimes on the ethnic orientation of organizations and social actors as well, which still remain firmly embedded in traditional and servile structures, norms and values. In the long run, such organizational structures not only undermine the norms and resources crucial to democracy, for example mutual trust and tolerance for those outside one's own group or ethnicity, ${ }^{12}$ 
but also place the organizational potential at the disposal of authoritarian politicians, who can rationalize its use for their own personal objectives. The ideal paradigm which underpins the notion of a civil society comprises a comprehensive political and social integration and an egalitarian, liberal, and fair political shaping of the public will.

The experience of the recent last decades has shown that each country exhibits its own specificities in the process of developing a deliberative democracy. Thus, it is impossible to implement the same model of democracy in all Central and Eastern European countries within a certain time frame and using analogous measures. A democratic civil society can be efficiently built only by attaining a balance between tradition, the specificities of the development of reforms, political culture, and the support for democratic norms and values. Social inclusion of foreign imitations (reproductions) carries its own risks. Western governments and benefactors have tried implanting the same paradigm of civil society into all countries and posing a unified set of demands to all, without taking into consideration the social and cultural contexts of specific countries. ${ }^{13}$ This list of unfavourable contextual conditions goes on, and considerably weakens the mobilizing, operational and organizational potential of civil and social groups, movements, and networks. In the theory there is a two-fold limitation on the democratic influence of civil society and on the communicative power of the administrative and political structures: on the one hand the existence of "antidemocrats" in the civil groups themselves; and on the other the willingness to engage the structures by means of the established traditional 'clientelist' channels of influence. In comparison to other countries in the region, Bosnia and Herzegovina demonstrates the most unfair income distribution. Violence, organized crime, internal insecurity and social apathy are on the rise. No one can tell when the minimum of social cohesion, a prerequisite for any society, may become entirely depleted. The tendencies toward the pluralisation and democratization in civil and social organizations are, overall, in the losing corner, since the share of "uncivil" society continues to grow. Eliminating xenophobic speech, stigmatization, and fundamentalism from the political discourse, the media, education, socialization etc. is essential to the development of a civil society. The crux of the issue is that the social actors in the current state of the Bosnian and Herzegovinian civil society are unable to establish meaningful communication with the informal public opinion, and are to a great degree focused only on themselves. One can discern a paradox of a kind characteristic for the civil society in Bosnia and Herzegovina, namely that the civil society is not only in conflict with the institutions of the administrative and political structures, but also with the political community as a whole. The distrust and apathy of citizens towards non-governmental organizations and social movements is also visible. The political apathy of the ethnically and religiously-segmented political community has in all likelihood been conducive to such a scenario, but a contributing factor must also have been the fact that the majority of the civil society structures do not draw on any local financial resources in Bosnia and Herzegovina, but are funded from foreign sources and by foreign benefactors.

\section{References}

Krasniqi, A. 2005: Zivilgesellschaft in Albanien, Universität Sofia, Sofia.

Merkel, W. 1999: Systemtransformation. Eine Einführung in die Theorie und Empirie der Transformationsforschung, Opladen: Leske + Budrich.

Merkel, W.; Puhle, H-J.; Corissant, A. 2003: Defekte Demokratie, Opladen: Leske + Budrich.

Müller, H. 1997: Zivilgesellschaft als friedenspolitisches Projekt? in: Vogt, W. R. 1997 (Hrsg.): Gewalt und Konfliktbearbeitung, Baden-Baden: Nomos.

Lauth, H. J. 2003: Zivilgesellschaft als Konzept und die Suche nach ihren Akteuren; in: Bauerkämper, A. 2003 (Hrsg.): Die Praxis der Zivilgesellschaft. Akteure, Handeln und Strukturen im internationalen Vergleich, Frankfurt und New York: Campus.

Kustura, M. 2005: Das Verhältnis von Zivilgesellschaft und Demokratie am Beispiel der Transformation von Bosnien und Herzegowina, in: Beiträge zur Ferienakademie 2005, Berlin: Rosa Luxemburg Stiftung.

Schmidt, S. 2000: Die Rolle von Zivilgesellschaften in afrikanischen Systemwechseln, in: Merkel, W. 2000 (Hrsg.): Systemwechsel 5; Zivilgesellschaft und Transformation, Opladen: Leske + Budrich.

Rüb, F. 1997: Warum scheiterte die Demokratisierung in Jugoslawien? oder: Gibt es eine „balkanische Kultur der Gewalt“? in: Pickel, G., Pickel, S. und Jacobs, J. 1997 (Hrsg.): Demokratie, Entwicklungsformen und Erscheinungsbilder im interkulturellen Vergleich, Frankfurt/Oder.

Rüb, F. 2000: Von der zivilen zur unzivilen Gesellschaft: Das Beispiel des ehemaligen Jugoslawien; in Merkel, W. 2000 (Hrsg.): Systemwechsel 5. Zivilgesellschaft und Transformation, Opladen: Leske + Budrich.

Salaj, B. 2009: Sozialer Zusammenhalt in Bosnien und Herzegowina, Sarajevo: Friedrich Ebert Stiftung. 